\title{
Cartilagem Articular e Osteoartrose
}

\author{
Articular Cartilage And Osteoarthrosis
}

Márcia Uchôa of Rezende; Arnaldo José Hernandez; Gilberto Luís Camanho; Marco Martins AmatuzzI

\section{INTRODUÇÃO}

A degeneração da cartilagem articular de causa principalmente mecânica é hoje uma das maiores preocupações dos ortopedistas.

A dificuldade em estabelecer modelos experimentais de artrose e a constante observação de fenômenos artrósicos secundários em patologias tipicamente ortopédicas como as seqüelas de fraturas e as instabilidades articulares, tem aproximado muito o cirurgião ortopedista do estudo da cartilagem e sua fisiologia.

A objetividade de nossa especialidade torna difícil e desconfortável este interesse e esta proximidade, pois o estudo da biologia, da estrutura da cartilagem e de sua degeneração é baseado em conceitos pouco habituais ao nosso hábito literário, porém, o conhecimento da fisiopatologia da osteoartrose tem demonstrado que uma solução biológica esta muito próxima, especialmente nos casos iniciais. O uso de drogas sistêmicas ou intra-articulares, de forma terapêutica ou preventiva, já faz parte do nosso arsenal .

A intenção deste artigo de revisão é trazer ao ortopedista, de forma resumida e objetiva, o estado da arte do estudo da fisiologia da cartilagem e da fisiopatologia da osteoartrose.

\section{A CARTILAGEM ARTICULAR NORMAL}

Sabe-se que a cartilagem articular é um tecido avascular, esparsamente celular, cujas características bioquímicas refletem principalmente a composição da matriz extracelular (Lanzer \& Komenda, 1990). Esta é hiperhidratada (conteúdo de água variando de 66 a 80\%), com 20-34\% de sólidos dos quais, 5-6\% são componentes inorgânicos (principalmente hidroxiapatita) e do restante orgânico, 48-62\% é formado por colágeno tipo II e 22-38\% por proteoglicanas. A rigidez e elasticidade do tecido são resultado da relativa incompressibilidade das moléculas de proteoglicanas. Os espessos feixes de fibras colágenas subjacentes e paralelas a superfície articular formam uma "pele" e provavelmente servem não somente como uma camada limitadora mas também para a distribuição de forças de compressão. As fibras da camada basal da cartilagem ficam perpendiculares à superfície e servem como âncora fixando a 100

\section{INTRODUCTION}

Currently, the mechanical degenerative changes of the articular cartilage are one of the primary concerns among orthopedic experts.

Both the difficulty in establishing experimental models of arthrosis and the regular observation of secondary arthritic phenomena in typically orthopedic diseases - like sequelae from fractures and articular instability - are aspects which close the orthopedist to the study of the cartilage and its physiology.

The objectivity of orthopedics becomes this interest and proximity hard. The study of either the cartilage biology or its structure and degeneration is based on concepts few common to our literature. However, the knowledge of the pathophysiology of the osteoarthrosis has demonstrated that a biological solution is very close, especially in the initial cases. The use of either therapeutically or preventively systemic or intra-articular drugs is already incorporated in our arsenal.

The aim of this review article is to offer briefly to the orthopedist the study of the cartilage physiology and the osteoarthrosis pathophysiology.

\section{THE NORMAL ARTICULAR CARTILAGE}

It is known that the articular cartilage is an avascular and poorly cellular tissue, whose biochemical characteristics reflect mainly the composition of the extracellular matrix (Lanzer \& Komenda, 1990). The extracellular matrix is hyperhydrated (the water content ranges from $66 \%$ to $80 \%$ ), with $20 \%-34 \%$ of solid components, $5 \%-6 \%$ of which is inorganic components (hydroxyapatite). Among the remaining organic content, $48 \%-62 \%$ is formed by type-ll collagen and $22 \%-38 \%$ is formed by proteoglycan. The rigidity and elasticity of the tissue are consequence of the relative decompressibility of the proteoglycan molecules. The thick bundle of collagen fibers underlying and paralleled to the articular surface form a "skin" and probably serve not only as a restrictive layer but also as a distributor of compression strengths. The fibers of the cartilage basal layer are perpendicular to the surface and they serve as an anchor, which fasten the decalcificated cartilage to the calcified zone and perhaps to the subchondral bone. In the intermediate zones, the fibers are randomly disposed. The oblique

ACTA ORTOP BRAS 8(2) - ABR/JUN, 2000 
cartilagem descalcificada à zona calcificada e talvez ao osso subcondral. Na zonas intermediárias as fibras se dispõem mais ao acaso. As fibras oblíquas provavelmente assistem na resistência a tensões. (Brandt e Mankin, 1993)

No metabolismo normal da cartilagem o condrócito dirige a reciclagem dos componentes da matriz (provável mediação enzimática) para satisfazer as necessidades internas de remodelação. No tecido adulto normal a homeostase da matriz é balanceada de forma a não haver nem perda, nem ganho de tecido. Estes processos são controlados por uma variedade de proteínas denominadas de fatores de crescimento e citocinas. (Pelletier e cols., 1993)

Fatores de crescimento [Insulin-like growth factor-1 (IGF-1) e Transforming growth factor-beta (TGF-b)] estimulam a síntese de agrecan (espécie predominante de proteglicana) e de colágeno. Podem modular as vias anabólicas e catabólicas do metabolismo do condrócito (Ex: podem aumentar a síntese de proteglicana) (Morales, 1990).

Proteases ácidas, glicosidases e sulfatases (= enzimas celulares autolíticas, principalmente as lisossômicas) mediam a degradação de proteglicanas (Ehrlich, 1985).

As citocinas tais como a interleucina-1 (IL-1), a interleucina-6 (IL-6) e o fator de necrose tumoral a (FNT-a) estimulam a degradação da matriz. A IL-1 é uma proteína de baixo peso molecular produzida por células mononucleares da sinóvia e pelo próprio condrócito, mediam a liberação de colagenase e proteases degradadoras de proteglicanas pelo condrócito. IL-1 estimula a síntese e liberação de estromelisina, que por sua vez é capaz de ativar a pró-colagenase dentro da cartilagem. O fator de necrose tumoral (FNT) tem atividade similar mas seu efeito sobre condrócitos é menos potente que o da IL-1. O papel da IL-6 na osteoartrose ainda não é bem definido. Sabe-se que in vivo ativam linfócitos $\mathrm{B}$ e $\mathrm{T}$ o que pode contribuir para as alterações da sinóvia encontradas na osteoartose (Pelletier e cols., 1993).

A cartilagem possui inibidores teciduais de metaloproteases que inibem as atividades da colagenase e estromelisina.(Dean e Woessner, 1985)

\section{A CARTILAGEM ARTICULAR PATOLÓGICA -OSTEOARTROSE}

Na osteoartrose, quer primária ou secundária, a cartilagem é o tecido com maiores aberrações do normal. Entre as alterações morfológicas, a cartilagem articular perde sua natureza homogênea e é rompida e fragmentada, com fibrilação, fissuras e ulcerações. Às vezes com o avanço da patologia, não resta nenhuma cartilagem e áreas de osso subcondral ficam expostas. Coloração histoquímica da matriz para proteoglicanas é desigual e a linha de separação entre a cartilagem calcificada e a zona radial é invadida por capilares. Forma-se clones de células (Moskowitz, 1973 e Muir, 1977). Osteófitos são encapados por cartilagem hialina e fibrocartilagem recém formadas mostrando grande irregularidade na sua estrutura (Marshall, 1969).

Entre as alterações metabólicas sabe-se que as taxas de síntese e de secreção de enzimas degradadoras de matriz pelos fibers probably aid in the resistance to tensions. (Brandt and Mankin, 1993)

In the normal metabolism of the cartilage, the chondrocyte guides the matrix components recycling (probably enzymemediated) to satisfy the internal needs of remodeling. In the normal adult tissue the homeostasis of the matrix is balanced to avoid either losses or gains of tissue. These processes are controlled by a variety of proteins named growth factors and cytokines. (Pelletier and cols., 1993)

Growth factors [Insulin-like growth factor-1 (IGF-1) and Transforming growth factor-beta (TGF-b)] stimulate the agrecan (a predominant type of proteoglycan) and collagen synthesis. They can modulate the anabolic and catabolic pathways of the chondrocyte metabolism (e.g., they can increase the proteoglycan synthesis) (Morales, 1990).

Acid proteases, glycosidases and sulphatases (autolytic cellular enzymes, mainly the lysosomal enzymes) mediate the proteoglycan degradation (Ehrlich, 1985).

Cytokines, such as interleukin-1 (IL-1), interleukin -6 (IL-6) and the alpha tumor necrosis factor (FNT-a) stimulate the matrix degradation. The IL-1 is a protein of low molecular weight produced by synovial mononuclear and chondrocyte cells. The IL-1 mediates the collagenase and proteases release, which degrade proteoglycan by the chondrocyte. The IL-1 stimulates the synthesis and the release of stromelysine, which is capable to activate the pro collagenase inside the cartilage. The tumor necrosis factor (FNT) has similar activity but its effect on chondrocytes is less potent than the effect of the $I L-1$. The role of the $I L-6$ in the osteoarthrosis is not well defined. It is known that in vivo they activate $B$ and T lymphocytes, which can contribute to the synovial changes found in the osteoarthrosis (Pelletier and cols., 1993).

The cartilage has tecidual inhibitors of metalloproteinases that inhibit the activities of the collagenase and stromelysine. (Dean and Woessner, 1985)

\section{THE PATHOLOGICAL ARTICULAR CARTILAGE-OSTEOARTHROSIS}

In either primary or secondary osteoarthrosis, the cartilage is the tissue with the largest deviations from the usual. Among morphologic changes, the articular cartilage loses its homogeneous nature and it is broken and fragmented, with fibrillation, fissures and ulcerations. Sometimes, according to the evolutive course of the disease, no cartilage remains and areas of subchondral bone are exposed. The staining histochemistry techniques of the matrix for proteoglycan are unequal and the separation line between the calcified cartilage and the radial zone is invaded for capillaries. A cluster of cells is formed (Moskowitz, 1973 and Muir, 1977). Osteophytes are covered by hyaline cartilage and fibrocartilage newly formed showing great irregularity in its structure (Marshall, 1969).

It is known that, among the metabolic changes, the synthesis and secretion rates of enzymes that degrade the matrix by chondrocytes are increased. Either the lysosomal or extralysosomal enzymatic activity is increased in several times. These enzymes 
condrócitos estão aumentadas. A atividade enzimática lisossômica e extralisossômica estão aumentadas várias vezes. Estas enzimas são as metaloproteases (colagenase, estromelisina e gelatinase) e hialuronidase que levam a: degradação dos agregados e perda de proteglicanas da matriz; clivagem de ácido hialurônico e de condroitina 6-sulfato; produção de proteglicanas incapazes de agregar; degradação do colágeno tipo II; degradação do arcabouço protéico da proteoglicana, ativação de outras enzimas tais como pro-estromelisina (degrada a matriz) e estromelisina, que ativa a colagenase que por sua vez destroi o colágeno o qual é, aparentemente, o fator principal na progressão da patologia e na destruição final da superfície (Ryu e cols., 1984 e Pelletier e cols., 1993).

A IL-1 é considerada como o primeiro agente para a degradação da matriz cartilaginosa uma vez que estimula a síntese e a secreção de várias enzimas degradativas na cartilagem inclusive colagenase latente, estromelisina latente, gelatinase latente e ativador tecidual de plasminogênio.(Pelletier e cols., 1993)

No início da osteoartrose há aumento da síntese de proteglicanas, colágeno, proteínas não colágenas, hialuronato, e ácido desoxiribonucleico (ADN) (Ryu e cols, 1984), indicando replicação celular e justificando os clones de condrócitos observados histologicamente (Marshall, 1969; Moskowitz, 1973; Muir, 1977). Mais adiante, a síntese de colágeno e proteoglicana continuam a aumentar em proporção à gravidade da lesão. Com a gravidade da doença a síntese de proteglicana cai significativamente, isto é, o condrócito "falha" (Mankin, 1971).

\section{A FISIOPATOLOGIA DA OSTEOARTROSE SECUNDÁRIA}

O ortopedista está habituado a tratar com a osteoartrose secundária ,que quase sempre é decorrente de desvios de eixo ou é de causa pós-traumática.

O modelo experimental de meniscectomia parcial em coelhos (Moskowitz, 1973), bem como o modelo canino de lesão do ligamento cruzado anterior (Marshall, 1969; Pond-Nuki, 1973; Muir, 1977) permitiram o estudo das alterações precoces da artrose secundária e o conhecimento de que a primeira alteração é o aumento do conteúdo de água da cartilagem, Não se sabe a causa desta hiperhidratação, mas se deve a uma falha nos restritores elásticos da trama de colágeno, permitindo que a proteglicana (hidrofílica), edemacie além do normal. Com a hiperhidratação da cartilagem, as proteglicanas são mais facilmente extraídas da matriz e há uma perda da orientação do colágeno próximo à superfície e afastamento anormal entre as fibras. Com isso, há uma perda da rigidez e elasticidade à compressão. As recém sintetizadas proteglicanas têm em sua composição maior proporção de condroitina sulfato e menor de querato-sulfato (McDevitt e cols., 1974). A agregação de proteglicana está prejudicada (McDevitt e Muir, 1976). Todas estas alterações ocorrem antes da fibrilação ou qualquer outra alteração morfológica ser evidente e enquanto a concentração de proteglicana é normal ou até aumentada (o que explica a diminuição generalizada de rigidez que ocorre nas áreas are metalloproteinases (collagenase, stromelysine and gelatinase) and the hyaluronidase, which led to degradation of the cellular cluster and loss of proteoglycans of the matrix. They also lead to the cleavage of the hyaluronic acid and the 6-sulphate chondroitin. They produce proteoglycans unable to cluster and they degrade the type-Il collagen; Also, they promote the degradation of the proteoglycan carcass, the activation of other enzymes, such as pro-stromelysine (which degrades the matrix) and stromelysine. Stromelysine activates the collagenase to destroy the collagen, which is the main factor in the progression of the disorder and the primary aspect in the final destruction of the surface (Ryu and cols., 1984 and Pelletier and cols., 1993).

The $I L-1$ is considered the first agent for the degradation of the cartilaginous matrix once it stimulates the synthesis and the secretion of several enzymes of degradation, including the latent collagenase, stromelysine, gelatinase and the tecidual plasminogen activator. (Pelletier and cols., 1993)

In the initial phase of osteoarthrosis there is an increased synthesis of proteoglycans, collagen, non-collagen proteins, hyaluronate, and desoxyribonucleic acid (DNA) (Ryu and cols, 1984), indicating cellular replication and justifying the chondrocyte cluster which are histologically observed (Marshall, 1969; Moskowitz, 1973; Muir, 1977). Later, the collagen and proteoglycan synthesis increases according to the severity of the damage. With the severity of the disease, the proteoglycan synthesis declines significantly, i.e., the chondrocyte "fails" (Mankin, 1971).

\section{PATHOPHYSIOLOGY OF THE SECONDARY OSTEOARTHROSIS}

The orthopedist often deals with the secondary osteoarthrosis, which is nearly always due to axis deviations or post traumatic.

The experimental model of partial meniscectomy in rabbits (Moskowitz, 1973) and the canine model of anterior ligament injury (Marshall, 1969; Pond-Nuki, 1973; Muir, 1977) allowed the study of the early changes of the secondary arthrosis and the knowledge that its first change is the increase of the cartilage water content. The cause of this hyperhydration is unknown. Perhaps it occurs due to a failure in the elastic restrictive action of the collagen net, which allows the proteoglycan (hydrophilic) to swallow abnormally. Due to the cartilage hyperhydration, proteoglycans are more easily extracted from the matrix. There is loss of the orientation of the collagen close to the surface and also an abnormal separation between the fibers. Thus, there is loss of the rigidity and elasticity to compression. The composition of newly synthesized proteoglycans has larger proportion of chondroitin sulphate and smaller proportion of keratosulphate (McDevitt and cols., 1974). The proteoglycan aggregation is harmed (McDevitt and Muir, 1976). All these changes occur before the fibrillation or prior to any other morphologic change is evident and when the proteoglycan concentration is normal or increased (this explains the general decrease of rigidity that occurs in the underlying fibrillation areas) (Kempson and cols., 1971). In the natural course of the disease, there is growth of cartilage focal ulcerations. It may be found proteoglycans loss and worsening in their aggregation, persistence of abnormalities in the composition of the glycosaminoglycans and 
adjacentes as de fibrilação) (Kempson e cols., 1971). Com a progressão da patologia, desenvolvem-se ulcerações focais da cartilagem. A perda de proteglicana, a piora na agregação das mesmas, a persistência de anormalidades na composição da glicosaminoglicanas e a diminuição de cadeias longas de condroitina-sulfato são encontradas. À medida que a perda de proteglicana aumenta, o conteúdo de água que inicialmente é grande, cai abaixo do normal.

A destruição da estrutura cartilaginosa e conseqüente exposição do osso subcondral alimentam o ciclo vicioso que encontramos nos pacientes portadores de osteoartrose.

\section{A FUNÇÃO DO HYALURONAN NAS ARTICULAÇÕES}

funções estruturais e lubrificadoras

Hyaluronan $(\mathrm{AH})$, nome alternativo para ácido hialurônico, que descreve a molécula do ácido independentemente do seu estado de dissociação do radical carboxila, nas articulações é sintetizado pelos condrócitos da cartilagem e pelos fibroblastos da camada sinovial conhecidos por células B. O AH sintetizado pelos primeiros se integra na matriz cartilaginosa enquanto que o $\mathrm{AH}$ do sinoviócito é liberado na cavidade articular (Abatangelo e Reagan, 1995).

A importância do $\mathrm{AH}$ na cartilagem articular está realcionada à manutenção da estrutura do agrecan. As moléculas de proteoglicanas (agrecan) se ligam a cadeias de $\mathrm{AH}$ formando agregados grandes de peso molecular de até $10^{8} \mathrm{Da}$. Estas macromoléculas são depositadas na rede de colágeno. A integridade dos agregados de proteglicanas são diretamente relacionados à integridade do $\mathrm{AH}$. Embora a concentração de $\mathrm{AH}$ na cartilagem aumente com a idade, seu peso molecular é reduzido o que leva a menores agregados de proteoglicanas. Como as moléculas recém sintetizadas de $\mathrm{AH}$ mostram poucas alterações com a idade supõe-se que haja uma quebra extracelular da molécula com a idade. Similarmente, na osteoartrose (OA), o AH é despolimerizado com conseqüente ruptura de agregados de proteoglicanas e conseqüente deterioração das propriedades mecânicas do tecido (Abatangelo e Reagan, 1995).

$\mathrm{O}$ AH com peso molecular de até alguns milhares de daltons está presente no líquido sinovial normal em concentrações de 2 a 4 mg/ml (Balazs e Denlinger, 1993). A combinação entre o alto peso molecular e a concentração elevada resultam numa solução altamente viscoelástica com funções de lubrificação e de absorção de choque sob altas forças de cizalhamento (Bothner e Wik, 1987). Um importante elemento na fisiopatologia da OA é a perda das propriedades viscoelásticas do líqüido sinovial devido à diminuição da concentração de do tamanho molecular do AH (Balazs, 1974). A viscoelasticidade diminuída do líqüido sinovial aumenta a susceptibilidade da cartilagem às lesões por sobrecarga (Pelletier e Martel-Pelletier, 1993). Assim, fica claro que as propriedades viscoelásticas do líqüido sinovial, devido ao $\mathrm{AH}$, exercem uma função no estado da articulação saudável e patológica. decrease of chondroitin sulphate long chains. As the proteoglycan loss increases, the initial water content falls below the normal.

The destruction of the cartilaginous structure and subsequent exhibition of the subchondral bone sustain a cycle in those patients with osteoarthrosis.

\section{THE FUNCTION OF HYALURONAN IN THE ARTICULATIONS structural and lubricant function}

Hyaluronan $(\mathrm{AH})$ is an alternative name for the hyaluronic acid, which describes the molecule of the acid apart from its dissociation state from carboxyl radical. In the cartilage either cartilage chondrocytes or fibroblasts of the synovial layer (also named B cells) synthesize hyaluronan. The AH synthesized by cartilage chondrocytes is integrated into the cartilaginous matrix while the AH of the synovial cell is released in the articular cavity (Abatangelo and Reagan, 1995).

The importance of the $\mathrm{AH}$ in the articular cartilage is related to the maintenance of the agrecan structure. The proteoglycan molecules (agrecan) join to the chains of AH to form large clusters whose molecular weight is up to $10^{8} \mathrm{Da}$. These macromolecules are deposited in the collagen net. The integrity of the proteoglycan cluster is directly related to the integrity of the $\mathrm{AH}$. Although the concentration of $\mathrm{AH}$ in the cartilage increases with aging, its molecular weight is reduced which lead to smallest proteoglycan attachés. As the newly synthesized molecules of AH show few changes with the aging it is supposed that there is an extracelular breakdown of the molecule with aging. Similarly, in the osteoarthrosis $(O A)$, the $A H$ is depolymerized with consequent rupture of proteoglycan attachés and subsequent deterioration of the mechanical properties of the tissue (Abatangelo and Reagan, 1995).

AH with a molecular weight of thousands of Daltons are present in the normal synovial fluid in concentrations ranging from 2-4 mg/ $\mathrm{ml}$ (Balazs and Denlinger, 1993). The combination between high molecular weight and concentration results in a solution highly viscous and elastic with either lubrication or shock absorption function under high strengths (Bothner and Wik, 1987). An important element in the pathophysiology of OA is the loss of viscous and elastic properties of the synovial fluid due to the decrease of concentration and molecular weight of the $\mathrm{AH}$ (Balazs, 1974). The reduced viscosity and elasticity of the synovial fluid increases the cartilage susceptibility to injuries due to overload (Pelletier and Martel-Pelletier, 1993). Thus, the viscous and elastic properties of the synovial fluid due to the AH exert a role in the healthy and pathological articulation. 


\section{CONCLUSÃO}

O conhecimento da fisiologia da cartilagem e da fisiopatologia da osteoartrose deverá, sem dúvida alguma auxiliar o ortopedista atuar de forma mais consciente na prevenção e na terapêutica precoce.

\section{CONCLUSION}

The knowledge of the cartilage physiology and the osteoarthrosis pathophysiology will

help orthopedists to act in the prevention and early treatment of the disease consciously.

\section{REFERÊNCIAS}

ABATANGELO, G.; O'REAGAN, M. Hyaluronan: biological role and function in articular joints. Eur. J. Rheum. Inflam. v. 15, p. 9-16, 1995.

BALAZS, E. A.; DENLINGER, J.L Viscosupplementation: A new concept in the treatment of osteoarthritis. J. Rheum., v.20, p. 7-9, 1993. Supplement 39

BALAZS, E. A. The physical properties of the synovial fluid and the special rotle of hyaluronic acid. In: HELFET, A. Disorders of the knee., 1. ed. Philadelphia, Lippincott, 1974. p. 63-75.

BRANDT, K.D.; MANKIN, H.J. Pathogensis of osteoarthritis. In: KELLEY, W.N.; HARRIS, E.D., Jr.; RUDDY, S.; SLEDGE, C.B. Textbook of rheumatology. 4. ed. Philadelphia, Saunders, 1993. p. 1355-84. (Section XV - Osteoarthritis and Polychondritis).

BOTHNER, H.; WIK, O. Rheology of hyaluronate. Acta Otolaryngo., v.442: p.25-30, 1987. Supplement.

DEAN, D. D.; WOESSNER, J. F., Jr. Extracts from human articular cartilage contain an inhibitor of tissue metalloproteinases. Biochem. J. 218: 277-84., 1985.

EHRLICH, M. G. Degradative enzyme systems inosteoarthritic cartilage. J. Orhtop. Res. v.3: 170-4, 1985.

KEMPSON, G. E.; SPIVEY, C.J.; SWANSON, S.A. V.; FREEMAN, M. A. R. Patterns of cartilage stiffness on normal and degnerative human femoral heads. J. Biomech. v.4: 597-605, 1971.

LANZER, W.L.; KOMENDA, G. Changes in articular cartilage after meniscectomy. Clin. Orthop. n. 252: 41-8, 1990.

MANKIN, H. J.; DORFMAN, H. D.; LIPPIELLO, L.; ZARINS, A. Biochemical and metabolica abnormalities in articular cartilage from osteoarthritic human hips. II. Correlation of morphology with metabolic data. J. Bone joint Surg. 53A:523-30, 1971.
MARSHALL, J.L. Periarticular osteophytes. Initiation and formation in the knee of the dog. Clin. Orthop. n.62, p.37-47, 1969.

McDEVITT, C. A.; MUIR, H. Biochemical changes in the cartilage of the knee in experimental and natural osteoarthritis in the dog. J. Bone Joint Surg. 58B: 94-101, 1976. p. 207-17.

McDEVITT, C. A.; MUIR, H.; POND, M.J. Biomechanical events in early osteoarthrosis. In: ALI, S.Y.; ELVES, M. W.; LEABACK, D. H. Normal and Osteoarthrotic Cartilage. (ed.) London, Institute of Orthopaedics, 1974. p. 207-17.

MORALES, T. I. Cartilage proteglycan homeostasis: role of growth factors. In: BRANDT, K. D. Cartiage Changes in Osteoarthritis. (ed.) Indianapolis, Indiana University School of medicine, 1990. p. 17-21

MOSKOWITZ, R.W.; DAVIS, W.; SANMARCO, J., MARTENS, M; BAKER, J.; MAYOR, M.; BURNSTEIN, A.H., FRANKEL, V.H. Experimentally induced degenerative joint lesions following partial meniscectomy in the rabbit. Arthritis Rheum. 16 (3): 397-405, 1973.

MUIR, H. Molecular approach to the understanding of arthrosis. Ann. Rheum. Dis. 36: 199-2, 1977.

PELLETIER, J.-P.; DIBATISTA, J.A.; ROUGHLEY, P.; McCOLLUM, R.; MARTEL-PELLETIER, J. Cytokines and inflamation in the cartilage degration. Rheum. Dis. Clin. North Am., v.19 n. 3: 545-65, 1993.

PELLETIER, J.-P.; MARTEL-PELLETIER, J. The patophysiology of osteoarthritis and the implication of the use of hyaluronan and hylan as therapeutic agents in viscosupplementation. J. Rheum. , v.20, 1924, 1993. Supplement.

POND, M. J.; NUKI, G. Experimentally induced osteoarthritis in the dog. Ann. Rheum. Dis. v.32, p.387-8, 1973

RYU, J.; TREADWELL, B.V.; MANKIN, H. Biochemical and metabolic abnormalities in normal and osteoarthritic human articular cartilage. Arthritis Rheum. 27 (1): 49-57, 1984. 